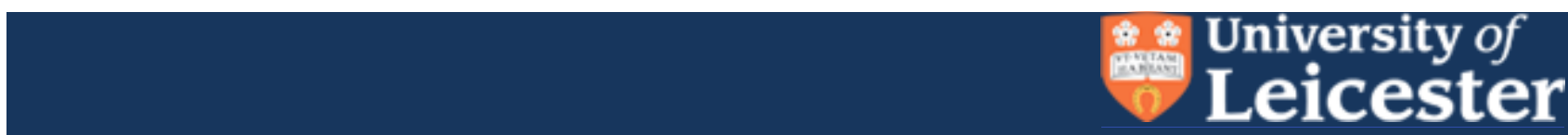

University of Leicester School of Law Research Paper No. 14-05

\title{
Legal Pluralism and Problems of Legal Application
}

\section{Francesco Belvisi}

University of Modena

\section{Abstract:}

In order to qualify a situation as a case of normative pluralism, it is essential that within the same social environment, rules of different origins are operative, i.e., they are valid and applied, so that the person in question can choose the norms that guide their own behaviour. This is the phenomenon which Boaventura de Sousa Santos defined as 'interlegality.'

The author does not propose a pluralist conception of applying law in a multicultural society, but defending a form of jurisdictional monism that is motivated by practical-normative reasons in accordance with the principle of non-discrimination. The claim, in other words, is that we must treat those who are different from ourselves with 'equal consideration and respect.' People belonging to different cultures from our own culture may de facto decide within their own group to let their own legal conflicts be dealt with by community 'jurisdictions.' At the same time, however, the democratic-constitutional legal system must guarantee the administration of justice in the 'last resort,' in accordance with the principle set out in the 'equal protection clause' (XIV am., sect. 1, US Const.) prescribing that the State cannot 'deny to any person within its jurisdiction the equal protection of the laws.' It is clear that very often the person asking for such protection will be the most vulnerable person within traditional communities: women.

Keywords: Pluralism, interlegality, non-discrimination

This text may be downloaded for personal research purposes only. Any additional reproduction for other purposes, whether in hard copy or electronically, requires the consent of the author. If cited or quoted, reference should be made to the following:

F. Belvisi, Legal Pluralism and Problems of Legal Application, University of Leicester School of Law Research Paper No. 14-05.

(c) 2014 Francesco Belvisi

University of Leicester School of Law Legal Studies Research Paper Series 


\section{Leicester-Modena Erasmus Conference: A Dialogue on Law and Rights}

Modena, 18 th. April 2013

Francesco Belvisi

Legal Pluralism and Problems of Legal Application.

I.

I teach both Philosophy of Law and Sociology of Law and, thus, I am inclined to deal with both the 'is' and the 'ought' of the law: The consequences are that - theoretically - my approach is a hybrid one, since it looks at philosophical questions from a sociological point of view, and empirical questions from a normative point of view. This is why, every so often I think of David Hume, who would be turning in his grave if he could hear one of my conferences or read one of my articles.

For me, however, it is not a question of deriving normative consequences from the "nature of the thing,' but of arguing, while respecting the 'coherence' of the thing. Someone might think - and they may be right - that at the end of the day, there is not a great difference between the two ways of proceeding.

However, since, I am influenced by the system theory of Niklas Luhmann, I know that the normative consequences that I derive, whilst taking the 'thing' seriously, are not necessary but contingent consequences: I may derive them in one way, but they could also be derived differently. For example, for me the pluralist and multicultural society is not only a mere fact, but also a value, which must be preserved. For someone else, however, it could be without doubt a fact, and yet one that must be disputed and changed, namely, a disvalue instead of a value. Thus, whilst starting from a normative position, my intention here is to produce a good argument about 'Legal pluralism and problems of legal application,' as opposed to an argument the validity of which hold with necessity.

First of all, the entire position of the problem must be contextualised: In my opinion, the question should be asked from the perspective of someone who finds herself in the situation we live in, which is that of a society not only pluralist, but also multicultural, and so characterised by substantial migratory phenomena that will see migrants to constitute ethnic-cultural minorities in the hosting society more often than not.

The notion of a 'multicultural society' is a sociological and empirical one. On the legal side, it corresponds to an 'experienced' normative pluralism, and not simply a theoretical normative pluralism. ${ }^{1}$ From the empirical point of view, a monistic concept of law, understood as a system of

\footnotetext{
- Paper presented at the Leicester-Modena Erasmus Conference: A Dialogue on Law and Rights, $18^{\text {th }}$ April 2013. I wish to thank Stefano Bertea and Jennie Huston for their advice on matter of English style and language.

${ }^{1}$ Franz v. Benda-Beckmann, 'Rechtspluralismus als Toleranzfrage' in Ch. Enders and M. Kahlo (eds), Diversität und Toleranz (mentis, Paderborn 2010) 116.
} 
norms, is no longer plausible and neither is the concept of law according to which the unity of a legal system is guaranteed by the sharing of constitutional values (with such values making a unitary system possible both from the logical-systematic point of view (integrity), and from a material, or substantive, point of view (a point of view that is capable of guaranteeing the integration of society). ${ }^{2}$ In fact, not only is the national legal culture pluralistic, but the cultures of the minorities within a society are defined by catalogues of values that occasionally may conflict with the constitutional values. ${ }^{3}$

By 'legal pluralism' one means a situation in which one single area of life, such as the cohabitation of couples, can be regulated by more than one legal system, or one series of rules. For instance, in Italy, the norms of Private Law govern civil marriage, those of Canon Law govern catholic marriage and customs govern the cohabitation of common law spouses. In other countries such as France, Spain, The Netherlands, or UK - Civil Law also regulates same sex marriages, or as in France and Germany - common law couples. Furthermore, the rules of International Private Law identify both the norms which may be applied in case of acknowledgement or annulment of the marriage between citizens of different nationalities, and also the criteria for deciding to what extent the foreign sentences of annulment may be effective. Finally, among certain cultural minorities, marriage is ruled by religious norms, as in the case of the Sharia for Islamic marriage, and the Torah for Jewish marriage.

In my opinion, in order to qualify a situation as a case of normative pluralism, it is essential that within the same social environment, rules of different origins are operative, i.e., they are valid and applied, so that the person in question can choose the norms that guide their own behaviour. This is the phenomenon which Boaventura de Sousa Santos defined as 'interlegality."

\footnotetext{
${ }^{2}$ The constitutional conception of the unity/integration of citizens into the State (legal system) was sustained by Rudolf Smend, 'Verfassung und Verfassungsrecht' (first published 1928), in R. Smend, Staatsrechtliche Abhandlungen (2nd edn, Duncker \& Humblot, Berlin 1968) 51-267. On which see Francesco Belvisi, Verso l'inclusione. La teoria delle istituzioni e l'integrazione sociale mediante il diritto (CLUEB, Bologna 2012) ch 4. Recognition of cultural and legal pluralism by the state legal system is perceived as a threat to its unity, thus the problem arises of the limits within which the (secular) state can tolerate diversity: see Uwe Volkmann, 'Die Einheit der Rechtsordnung vor den Herausforderungen der Toleranz', in Ch. Enders and M. Kahlo (eds), Diversität und Toleranz (mentis, Paderborn 2010) 125.

${ }^{3}$ In his pioneering contribution, with regard to the subject in question, Pietro Rescigno, 'Pluralità di culture e unicità di ordinamento giuridico: i problemi di una società multirazziale' in $\mathrm{B}$. Perrone (ed), Realtà e prospettive dell'obiezione di coscienza. I conflitti degli ordinamenti (Giuffrè, Milan 1992) 223, first maintains that 'the pluralist ideal included in the Constitutional charter must [...] be compatible with the formulation of a legal system as a unitary and general system' (225), but then specifies that the legal system, in order to take into account the pluralist social situation 'becomes a system based on plurality' (226f), which may 'justify differentiated legal treatments' (228, see also 231). In fact, 'when it is a question of basic requirements which affect necessities, needs, the material condition of the individuals, [it is] indispensible to return to unity: unity of the system, which however does not mean unitariness of the legal system' (232). With the term 'system' the author means here not simply a set of legal rules (legal order), but also jurisdiction as the institution of the application of the rules.

${ }^{4}$ See Boaventura de Sousa Santos, 'Law: A Map of Misreading. Toward a Postmodern Conception of Law' (1987) 14 JLaw \& Soc 279, 298; idem, 'Stato e diritto nella transizione post-moderna. Per un nuovo senso comune giuridico' (1990) 42 Sociologia del diritto 5, 28-29.
} 
Paradoxically, however, I end up not proposing a pluralist conception of applying law in a multicultural society, but defending a form of jurisdictional monism that is motivated by practicalnormative reasons in accordance with the principle of non-discrimination. I claim, in other words, that we must treat those who are different from ourselves with 'equal consideration and respect.' People belonging to different cultures from our own culture may de facto decide within their own group to let their own legal conflicts be dealt with by community 'jurisdictions.' At the same time, however, the democratic-constitutional legal system must guarantee the administration of justice in the 'last resort,' in accordance with the principle set out in the 'equal protection clause' (XIV am., sect. 1, US Const.) prescribing that the State cannot 'deny to any person within its jurisdiction the equal protection of the laws. ${ }^{5}$ It is clear that very often the person asking for such protection will be the most vulnerable person within traditional communities: women.

Having summarised my position, I can now develop my argument.

\section{II.}

The guiding principle of my remarks is the principle of non-discrimination, which is contained in art. 3 of the Italian Constitution of 1948. The first comma of this article reads thus:

All citizens have equal social dignity and are equal before the law, without distinction on the grounds of gender, race, language, religion, political opinion or personal or social conditions.'

This principle is connected to the identity and dignity of the person, because non-discrimination is the other face of equality. Thus, as Giuseppe Zaccaria notices, it consists 'of allowing all members of society to give themselves a cultural identity. ${ }^{6} \mathrm{We}$ are formally equal, despite our differences. In a legal sense, the recognition of identity and the rights pertaining to a person constitute human dignity. ${ }^{7}$ A person is subject to discrimination, and so is offended in her dignity and humility, $^{8}$ if the legal system does not allow her to lead a lifestyle that she has chosen, possibly in contrast with specific fundamental rights, and she regards as reflecting an existential plan consistent with her own religious, moral and traditional values.

Consequently, with regard to the 'fact' of the diversity of the person, there exists a genuine right to pluralism, in which the personal differences of 'gender, race, language, religion, political

\footnotetext{
${ }^{5}$ On the contrary, see the case law of the European Court of Human Rights, which - in the past - had limited the field of application of art. 9 of the European Convention for Human Rights (1950), where an applicant had voluntarily chosen her own situation: see Samantha Knights, 'Approaches to Diversity in the Domestic Courts: Article 9 of the European Convention of Human Rights' in R. Grillo, et al. (eds), Legal practice and cultural diversity (Ashgate, Farnham 2009) 290.

${ }^{6}$ Giuseppe Zaccaria, La comprensione del diritto (Laterza, Rome-Bari 2012) 178.

${ }^{7}$ On the legal meaning of the concept of 'dignity' see Francesco Belvisi, 'Dignità umana: una ridefinizione in senso giuridico’ (2012) 38 Ragion Pratica 161.

${ }^{8}$ On the concept of 'humiliation' see Avishai Margalit, The Decent Society (Harvard UP 1996); Richard Sennett, Respect. In an Age of Inequality (Penguin, London 2002).
} 
opinions,' etcetera, are respected. ${ }^{9}$ This is why, I believe, it is right to take questions concerning multicultural identity seriously. In other words, not the normative universe but rather the normative pluriverse $e^{10}$ has to face in a situation of legal pluralism. Thus, I maintain that these questions can be neither decided by strictly applying State Law, nor simply treated according to the tolerance principle, which tend to merely allow for a modus vivendi, ${ }^{11}$ and so does not genuinely recognise the rights and identity of a person. Related, I claim that these questions should be dealt with from a negotiating point of view ${ }^{12}$ or - better still - in accordance with practises of settlement or 'accommodation.' The latter consists of 'practises through which the law, or social actors operating in its shadow, are sensitive to, take into account and make room for values and meanings which differ from their own., 13

The reason supporting my view is that the typical relevant courses of conduct I am referring to consider, for example, the cases of polygamous marriage, displaying of religious symbols, following of certain food rules, wearing certain types of clothing, practising particular rituals, following a particular school education - are (very often) prescribed by institutional rules. These rules arise within those which Robert Cover has defined 'nomoi groups. ${ }^{14}$ These are 'jurisgenetic' groups, i.e., they produce law for those who belong to them. This law is justified and interpreted from within narratives and founding myths that are contained in the most diverse 'texts,' such as sacred scriptures, epic poems, tragedies, comedies, constitutional acts, etcetera. On this basis, the groups successfully protect their own collective identity and effectively control the behaviour of those who belong to them.

These groups are cultural communities, whose norms constitute institutions which are legitimized by the fundamental values of the community, and so they obtain great consensus. The forms of action which derive from them are valuable, i.e., they are worthy for those who practise them, ${ }^{15}$ irrespective of the fact that forms of action correspond to institutions (like the hierarchy in relationships between man and woman, polygamy, wearing certain costumes, etcetera) which may

\footnotetext{
${ }^{9}$ Similarly, Prakash Shah, 'Transforming to Accommodate? Reflections on the Shari'a Debate in Britain' in R. Grillo, et al. (eds) Legal practice and cultural diversity (Ashgate, Farnham 2009) 73, 81, emphasises the 'right to be different' as a crucial question in a pluralism situation.

10 James Tully, Strange Multiplicity. Constitutionalism in an Age of Diversity (Cambridge UP 1995) 131, speaks of 'multiversum' in reference to the 'world of constitutionalism.'

${ }^{11}$ John Gray, Two Faces of Liberalism (New Press, New York 2000) 5f, 19f, 25, 32f, and ch 4, elaborates a theory of the modus vivendi, providing an ethical-political justification for it, based on the redefinition of liberal tolerance in view of peaceful coexistence. The starting point is given by the acknowledgement of the inevitability of diversity and the consequent abandonment of pursuing any form of universal consensus on values.

${ }^{12}$ See, lastly, F. Colom González, 'Justicia intercultural. El pluralismo jurídico y el potencial de la hermenéutica normativa' (2009) 33 Revista Internacional de Filosofía Política 7.

${ }^{13}$ Roger Ballard, et al. 'Cultural Diversity: Challenge and Accommodation' in R. Grillo, et al. (eds) Legal practice and cultural diversity (Ashgate, Farnham 2009) 9, 20.

${ }^{14}$ See Robert Cover, 'The Supreme Court, 1982 Term -- Foreword: Nomos and Narrative' (1983) 97 HarvLR 4.

${ }^{15}$ Joseph Raz, Value, Respect and Attachament (Cambridge UP 2001) ch 1, paras $5 \mathrm{f}$.
} 
be incompatible with the principles and the rules of the official legal system of the host society ${ }^{16}$. Thus, we must both take the institutional rules of these minorities seriously and must not underestimate their normative force and their effectiveness. This means to also treat the people who follow them with 'equal concern and respect,' i.e., in accordance with the principle of nondiscrimination. According to Ronald Dworkin, 'no self-respecting person who believes that a particular way to live is most valuable for him can accept that this way of life is base or degrading., 17

In fact, culture possesses an existential meaning for any human being, and thus it becomes difficult to legitimately and successfully criticise the institutions of others as unreasonable, unworthy or wrong by taking up an external, detached, 'objective' point of view. ${ }^{18}$ As a result , if the State law does not recognise, and even opposes, the fundamental values of the nomoi and the behaviours consistent with them, it ends up threatening not only the identity, but also the very existence of the groups concerned. For this reason, groups, minorities and communities put in place reactive strategies to defend their own culture (reactive culturalism $^{19}$ ), of a traditionalist or fundamentalist nature, with the result that often these groups lead their own parallel life. This means that the behaviours not accepted by the dominant legal system become invisible in the society. And yet they are far from unregulated. In fact they are regulated in the submerged world of behaviours governed by the 'original' nomos. A good example of this scenario is the case of polygamy in Great Britain, in which, indeed, since the 70's of the last century, there has evolved 'a legal underground in which [it] is perpetrated. ${ }^{20}$ This is why it is not surprising if cultural and religious communities ask the State to have the possibility to exercise their own jurisdiction, more or less exclusive, in the subjects that they maintain to be fundamental to ensuring the collective identity of the group and the personal identity of its members.

The question we should be asking ourselves is, then, how can the State legal system deal with these questions posed by the cultural difference, whilst respecting it, according to what is required by the principle of non-discrimination?

\footnotetext{
${ }^{16}$ With reference to the situation in the Islamic states, Sherman A. Jackson, 'Legal Pluralism between Islam and the Nation-State: Romantic Medievalism or Pragmatic Modernity?' (2006) 30 FordhamInt'lLJ 158, 172, maintains that 'there is an entire universe of legal rights and obligations that are authoritative and deeply felt in the hearts and minds of people yet totally independent of the State.'

${ }^{17}$ Ronald Dworkin, 'Why Liberals Should Care about Equality' in idem, A Matter of Principle (Harvard UP 1985) 205, 206.

${ }^{18}$ See Arnold Gehlen, Prospettive antropologiche (first published 1961, It. trans. il Mulino, Bologna 1987) 109.

${ }^{19}$ Ayelet Shachar, Multicultural Jurisdictions (Cambridge UP 2001) 35ff, 43f, 59-61.

${ }^{20}$ Federica Sona, Polygamy in Britain, paper for the Observatory for Liberties and Religious Institutions (OLIR 2005) $<\mathrm{http}$ //www.olir.it/areetematiche/104/documents/Sona_Polygamy_in_Britain.pdf $>$ accessed 31 January 2013; see also Carlo Ricci, 'Shari'a Courts in Gran Bretagna: riflessioni sulle forme di giustizia interna alla comunità islamica inglese? (2009) 20 I diritti dell'uomo 2, 25.
} 
One point must be held firm: the institutions of the minority groups propose some patterns of behaviour that are just as worthy as those proposed by our institutions. According to the phenomenon of the reactive culturalism, it is not only highly unlikely but also arguably unjust that their practices may be overruled, or even effectively opposed, via measures of legal repression.

The institutional answers may be the most diverse, and may range from the French 'universalist model,' statist and assimilationist, which simply deny the problem, to the Canadian 'particularist model,' shaped by jurisdictional pluralism. ${ }^{21}$ The particularist model, proposes a millet system, in which the single communities - and in particular those organised on a religious basis - have independent and sometimes exclusive jurisdiction, for matters which concern their collective identity - in particular, the personal statute, family law and law of succession ${ }^{22}$, without there being at the level of the State legal system, a uniform law of the legal branch concerned. The main limit of this model is that which Ayelet Shachar defined as the 'paradox of multicultural vulnerability': because of the masculine and patriarchal order which is characteristic of many communities, the jurisdictional independence of the cultural minorities recognised by the State may result in aggravating the oppression of the most vulnerable people, such as women and children, when the community courts apply traditional rules ${ }^{23}$.

From the point of view of moderate multiculturalism, Shachar proposes, instead, a multicultural jurisdiction, intended in the sense of a concurrent jurisdiction between the minority one and that of the State $^{24}$. The limit of the competing jurisdictions proposed by Shachar as a form of joint governance, is that it gives too much importance to the community and its presumed collective identity, so that this solution promotes the conception which sees society as an archipelago of cultural islands, almost separated from society as a whole, within which collective rights are recognized $^{25}$.

\footnotetext{
${ }^{21}$ See Veit Bader, 'Legal Pluralism and Differentiated Morality' in R. Grillo, et al. (eds) Legal practice and cultural diversity (Ashgate, Farnham 2009) 49.

${ }^{22}$ See the examples presented in Ayelet Shachar, Multicultural Jurisdictions (Cambridge UP 2001) 78-85.

${ }^{23}$ See ibidem, 2f. A similar argument, focussing on group rights, was made by Susan M. Okin, 'Is Multiculturalism Bad for Women?' (first published 1997) in J. Cohen, et al. (eds) Is Multiculturalism Bad for Women? (Princeton UP 1999) $9,12 \mathrm{f}$.

${ }^{24}$ This proposal was agreed with by the Archbishop of Canterbury, Rowan Williams, in the famous conference held at the Royal Courts of Justice, on the 07 February 2008: Civil and Religious Law in England: a Religious Perspective $<$ http://rowanwilliams.archbishopofcanterbury.org/articles.php/1137/archbishops-lecture-civil-and-religious-law-inengland-a-religious-perspective > accessed 31 January 2013. On his conference see: Roger Ballard, et al. 'Cultural Diverdity: Challenge and Accommodation' in R. Grillo, et al. (eds) Legal practice and cultural diversity (Ashgate, Farnham 2009) 16; Prakash Shah, 'Transforming to Accommodate? Reflections on the Shari'a Debate in Britain' in R. Grillo, et al. (eds) Legal practice and cultural diversity (Ashgate, Farnham 2009) 77.

${ }^{25}$ For 'collective rights' or group rights, here it means those rights which protect the cultural identity features of a community, such as - for example - the right to express oneself in their own language, or wear traditional garments. These rights may be enjoyed individually (uti singuli) and, thus, fall under the liberal tradition of rights, or the holder of those rights is the collective in that as such (uti universi), it is considered a distinct legal subject. This last conception can be found within the organicist or communitarian doctrines of the law. An example can be found in Charles Taylor, Multiculturalism and 'the Politics of Recognition' (Princeton UP 1992). For the anti-liberal consequences of the
} 
On the contrary, I move from a secular and personalist point of view. From this perspective, communities and cultures - despite the important meaning they carry for people - can only be protected indirectly, via the guarantees provided to human beings by the State system.

In order to settle multicultural legal conflicts, in general, and those in which women - very often as the offended or discriminated parties (especially in a family environment ${ }^{26}$ ) - are implied in particular, the solution I would propose is that of promoting - according to Denise Réaume 'culturally sensitive jurisdiction. ${ }^{27}$ In reality, this should concern a judicial activity which pronounces decisions 'sensitive' not only for the cultural minority in question, but for all the cultures in play - the minority one and also the majority or 'official' one. ${ }^{28}$

To this end, then, the decisional activity should be of a prudential nature and specifically oriented towards the fundamental principles of the constitution: freedom, equality, solidarity, dignity, etcetera. ${ }^{29}$ In this way the jurisdiction may have a certain success, also as far as social integration is concerned, only insofar as it is able to respect the conditions 'represented' by pluralism. With the words of Lord Justice Arden, appeal court judge, the parties 'may observe different traditions and practices [...] That must be expected and respected in the jurisdiction [since] the court must pay appropriate regard to these differences. ${ }^{30}$

With regard to cultural diversity both the paternalism of those who want to teach and impose on others how they should behave, and also the indulgence however tolerant of diversity are counterproductive. ${ }^{31}$ Rather, the judicial activity itself should be formed as momentum for the respectful criticism of the foreign practices and institutions, which are followed in a society

conception, see the contributions of: Ermanno Vitale, 'Introduzione. Le nuove frontiere della teoria dei diritti' in E. Vitale (ed) Diritti umani e diritti delle minoranze (Rosenberg \& Sellier, Torino) 11; Anna E. Galeotti, 'I diritti collettivi' in ibidem, 30; Paolo Comanducci, 'Quali minoranze? Quali diritti? Prospettive di analisi e classificazione', in ibidem, 47.

${ }^{26}$ On the discriminating and identity-building function of family law see Ayelet Shachar, Multicultural Jurisdictions (Cambridge UP 2001) 49-55.

${ }^{27}$ Denise Réaume, 'Moral and Legal Responses to the Multi-cultural, Multi-ethnic State', in M.M. Karlsson, et al. (eds) Recht, Gerechtigkeit und der Staat (Duncker \& Humblot, Berlin 1993) 251, $256 \mathrm{f}$.

${ }^{28}$ It is a median proposal between the traditional 'procedural approach' and that 'based on difference'. For these models see Avigail Eisenberg, 'Diversity and Equality: Three Approaches to Cultural and Sexual Difference' (2003) 11 The Journal of Political Philosophy 41, 50-62. The third would be the 'universalist approach of rights' (42-46).

${ }^{29}$ For the meaning I attribute to the notion of 'principle' see Francesco Belvisi, 'I diritti fondamentali nella società multiculturale' (2012) 38 Diritto e società 1.

${ }^{30}$ Arden LJ, in Khan $v$ Khan [2007], quoted in Samantha Knights, 'Approaches to Diversity in the Domestic Courts: Article 9 of the European Convention of Human Rights' in R. Grillo, et al. (eds), Legal practice and cultural diversity (Ashgate, Farnham 2009) 286.

${ }^{31}$ This last attitude often characterizes that kind of case law, which upholds the 'cultural defence' too superficially.

A German case, which was much talked about in Italy, since an Italian was involved as culprit, was that decided by the Landgericht Bückeburg, on the $14^{\text {th }}$ of March 2006: see Fabio Basile, Immigrazione e reati culturalmente motivati (Giuffrè, Milan 2010) 255f. A considerable part of Italian case law does not seem to be subject to the danger of superficial indulgence, which seems to go, instead, to the opposite extreme: that of manifesting a 'judicial idiosyncrasy to culturally oriented crimes', which at times 'ends up translating into [...] a surreptitious form of exclusion of the "cultural foreigner"': see Ciro Grandi, 'I reati culturalmente motivati nella giurisprudenza italiana: una categoria negletta?' in O. Giolo and M. Pifferi (eds) Diritto contro: meccanismi giuridici di esclusione dello straniero (Giappichelli, Turin 2009), resp. 204 and 195. 
different from their original one. This may mean that the judge, in searching for an appropriate solution, reflects the normative pluralism, according to a quasi rule-producing decision-making strategy. In this model, in applying the law the judge takes into consideration both foreign rules, and principles and norms of her own legal system, in order to 'put together' a new rule, a hybrid of the norms and principles of the systems considered.

Legally, belonging to a cultural group cannot be conceived as an ascriptive status (by force), nor should the cultural choice of an individual weigh on an individual like a sentence. On the contrary, the elective nature of these aspects should be fully recognised (by will), so that people must be able to benefit from the guarantees provided by the legal system of the country in which they live, even if they have initially chosen a traditional way of life, which does not foresee that kind of protections $^{32}$ and despite any existence of specific group rights.

\section{III.}

The rise of the hard cases is indicative of the problem of the 'unhappy' integration ${ }^{33}$ of the person, which can happen on two distinct levels: that of integration in their own group (which can imply also only minimal integration into the society as a whole: for example, the married woman in a polygamous marriage who accepts her own condition); and that of the inclusion in the host society (which implies a centrifugal integration with regard to their own group: for example, the woman cast out from her group who turns to the protection of the State legal system in order to improve her own personal economic conditions). The passage from one integrative form to the other is made possible by the so called 'right to exit,' that is, by a person's freedom to leave their own group, which sparks off the general protection of the State legal system. The protection of the legal system, though, does not intervene only in the case of definitive abandonment by a person of their own culture and group, but also in the instance of even only a partial or temporary distancing. ${ }^{34}$

Furthermore, as far as the legal protection of these people is concerned, those who are different even with regard to the minority group they belong to, the most appropriate procedure may not be

\footnotetext{
32 In a similar way, Susan M. Okin, 'Is Multiculturalism Bad for Women?' (first published 1997) in J. Cohen, et al. (eds) Is Multiculturalism Bad for Women? (Princeton UP 1999) 20, asks: 'When a woman from a more patriarchal culture comes to the United States (or some other Western, basically liberal, state), why should she be less protected from male violence than other women are?'. In my opinion, though, this kind of protection is not the only one, nor the main one. Rather, it should constitute a 'subsidiary' form of protection.

33 'Unhappiness' means having to choose the second best option: That for which in the difference (which requires as a principle of justice that equal cases are treated equally and different cases are treated differently) we resort to the principle of formal equality (according to which all people are equal in the eyes of the law) and to the legal provisions, but in respect of the initial difference, as required by the principle of human dignity. On the concept of 'happy/unhappy integration' see Gianfrancesco Zanetti, Political Friendship and the Good Life (Kluwer, The Hague 2002).

${ }^{34}$ However, the right to exit may provide a guarantee only prima facie, since that which the dissident is faced with is often solely a dramatic situation in which the woman finds herself doubly discriminated against - in her community and in society at large - and in the impossibility of surviving outside the oppressive relations which govern the community life.
} 
that which ends in an authoritative decision like that of the judge, but a settlement which tries to mediate between the parties involved. ${ }^{35}$ In fact, in questions in which women are implied in the vast majority of cases, such as conjugal ones (divorce, repudiation) or familiar ones (custody of children, home authority, heredity), or in those that are directly opposed to their community, ${ }^{36}$ they risk losing out in every case: If the State judge recognises their just rights, they are marginalised or expelled from the group; if they lose the case they are forced to continue being subject to mistreatment. In these cases - of which real examples can be found, for example, in the protection of the right to physical integrity against the danger of being subject to a genital mutilation - some authors formulate the hypothesis that it is better to find a compromise solution which safeguards both traditional rules and customs, and women's rights, but without making them run the risk of no longer being accepted by their group. ${ }^{37}$

Finally, the solution to these hard cases requires that the reconstruction of the case and the identification and interpretation of the norms happen in a - Weberian - 'understanding' way, which is informed to the principles of equal consideration and respect, and cultural pluralism. ${ }^{38}$ So, the action ruled by institutional norms should be understood as based on the intention of the actor, according to the 'presumption' of the value of the institution in question, it should be judged according to constitutional principles. For example, on one hand, in consideration of the respect of the foreign culture and pluralism, this could lead to the recognition of polygamous marriage celebrated within the community, despite conflict with the principle of moral and legal equality between spouses (art. 29, par. 2 It. Const.); on the other hand, it implies that - in order to respect personal dignity - criticism of the institution by jurisdictional means, which, in the case of conflict between spouses, grants protection to the weaker party - the woman -with regard to separation and divorce, support, custody of the children, etc., through the application of articles 3 and 29 of the It.

\footnotetext{
${ }^{35}$ I have dealt with the pattern of mediation as an alternative model to that of the judicial decision in Francesco Belvisi, 'Diritti e giustizia in una società multiculturale. Le sfide al diritto nell'Italia di oggi' (2002) 113 Il diritto ecclesiastico 447-453; Francesco Belvisi, 'Identità, minoranze, immigrazione: com'è possibile 1'integrazione sociale?' (2002) 4 Diritto, immigrazione e cittadinanza, 27-30. See also, Ayelet Shachar, Multicultural Jurisdictions (Cambridge UP 2001) chs 5f.

${ }^{36}$ The case of Santa Clara Pueblo v. Martinez, 1978 is well known. See: Ayelet Shachar, Multicultural Jurisdictions (Cambridge UP 2001) 18-20; M.C. Lâm, 'Between Nationalism and Feminism: Indigenous Women, Community, and State' in R.A. Shweder, et al. (eds), Engaging Cultural Differences. The Multicultural Challenge in Liberal Democracies (Russel Sage Foundation, New York 2002) 282-284.

${ }^{37}$ The principle is that of accommodation: see Ayelet Shachar, Multicultural Jurisdictions (Cambridge UP 2001 ) ch 5.

${ }^{38}$ On the difficulty of determining the facts and identifying the rule to be applied in pluralist situations see Francesco Belvisi, 'Situando l'analisi: pluralismo normativo e tutela giuridica dei soggetti vulnerabili nella società multiculturale', in Th. Casadei and L. Re (eds) Differenza razziale, discriminazione e razzismo nelle società multiculturali (Diabasis, Reggio Emilia 2007) vol 1, 171-187; for the criminal cases see Baldassare Pastore, 'Identità culturali, conflitti normativi e processo penale' in B. Pastore and L. Lanza, Multiculturalismo e giurisdizione penale (Giappichelli, Torino 2008) 5061.
} 
Const., and Italian Family Law. ${ }^{39}$

Thus, according to the principle of non-discrimination, in my opinion, it is not just simply a question of making 'rules coming from other legal systems' effective within State law, but also of acknowledging the normative value of the institutions of different cultures and - by respecting them - apply the rules that constitute them, i.e., 'accommodating them' in compliance with the fundamental principles of the constitution.

\footnotetext{
${ }^{39}$ For more in-depth exploration on the topic see Francesco Belvisi, 'Una riflessione normativa per la società multiculturale. L'esempio del matrimonio islamico', (2003) 5 Diritto, immigrazione e cittadinanza 42-47. For a different argument, see Bhikhu Parekh, Rethinking Multiculturalism: Cultural Diversity and Political Theory (Palgrave, Basingstoke 2000), 282-292. The criteria that I propose in the text can find a certain confirmation in the judicial standard practice of International Private Law, which follows the "two-stage theory": see Erik Jayme, 'Diritto di famiglia: Società multiculturale e nuovi sviluppi del diritto internazionale privato', (1993) 29 Rivista di diritto internazionale privato e processuale 301f; Luigi Melica, 'Lo straniero extracomunitario. Valori costituzionali e identità culturale', in S. Bartole, et al. (eds), La tutela giuridica delle minoranze (Cedam, Padova 1998), 205; Nicola Colaianni, 'Poligamia e principi del 'diritto europeo', (2002) 19 Quaderni di diritto e politica ecclesiastica 242ff.
} 